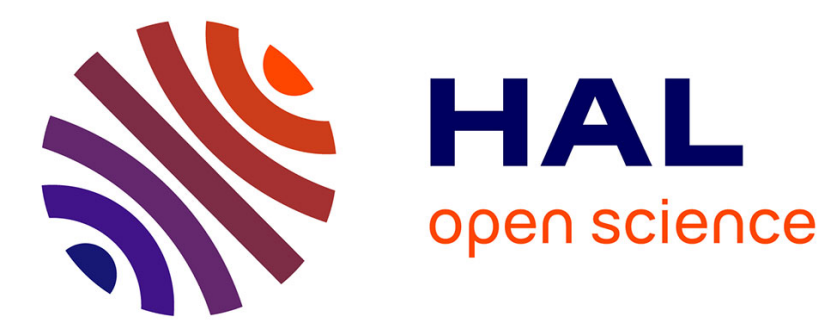

\title{
Systems Interoperability Evaluation through Formalisation of Semantic Relationships
}

\author{
Esma Yahia, Alexis Aubry, Hervé Panetto
}

\section{To cite this version:}

Esma Yahia, Alexis Aubry, Hervé Panetto. Systems Interoperability Evaluation through Formalisation of Semantic Relationships. INSIGHT - International Council on Systems Engineering (INCOSE), 2011, 14 (4), pp.9-10. 10.1002/inst.201114411 . hal-00653690

\section{HAL Id: hal-00653690 \\ https://hal.science/hal-00653690}

Submitted on 20 Dec 2011

HAL is a multi-disciplinary open access archive for the deposit and dissemination of scientific research documents, whether they are published or not. The documents may come from teaching and research institutions in France or abroad, or from public or private research centers.
L'archive ouverte pluridisciplinaire HAL, est destinée au dépôt et à la diffusion de documents scientifiques de niveau recherche, publiés ou non, émanant des établissements d'enseignement et de recherche français ou étrangers, des laboratoires publics ou privés. 


\section{Systems Interoperability Evaluation through Formalisation of Semantic Relationships}

Esma Yahia, esma.yahia@incose.org; Alexis Aubry, alexis.aubry@incose.org; and Hervé Panetto, herve.panetto@incose.org

To remain competitive, enterprises increasingly need to collaborate with each other and evolve into extended enterprises or networked enterprises. These organisation configurations incite the different enterprise systems to be interconnected in spite of their functional, structured, and conceptual heterogeneity. Typically, these features refer to the interoperability that can be defined as the capacity of systems or organisations to provide or to accept services and to use those services to effectively operate together (IEEE 1990). To promote added value creation through this collaborative activity, there is an increasing demand for information exchange and knowledge sharing among the various information systems (known as technical interoperability). Information and communications technologies and implementing standards can contribute to solving (at least partially) the barriers to technical interoperability. However, these efforts remain insufficient to guarantee interoperability at the conceptual level, where enterprises in a networked system can share information with each other, interpret this information correctly according to a common business semantics and then use this information to achieve a global mission.

\section{Interoperability Evaluation}

Interoperability is not visible when it is effective, but the lack of interoperability poses a series of challenging problems to the industrial community. Indeed, it leads to significant costs, largely attributable to the time and resources spent when exchanging information. This increased cost and the resulting delays in providing expected services can severly hurt enterprises' global performance. For example, a 1999 study by Tassey, Brunnermeier, and Martin estimated that in that year the lack of interoperability drained at least USD 1 billion per year from the United States automotive supply chain.

We propose to address the measurement of enterprise interoperability in order to allow any enterprise to fully evaluate its own capacity to interoperate with others, and therefore to anticipate possible problems before a partnership. To do this we must first define the indicators and metrics to quantify, and then we must qualify the interoperation between the enterprise systems.

\section{Formalizing the Interoperability Relationship}

We propose at first to provide a formal mathematical definition of the interoperability relationship between the enterprise systems models (Yahia et al. 2011). For this reason we identify the necessary and sufficient model semantics by defining a semantically recursive structure composed of aggregates, what we call semantic blocks. These semantic blocks will eventually guide the formalization and then facilitate the evaluation of the interoperability relationship through mathematical functions.

\section{Measures of the Potential Interoperability and its Effectiveness}

Interoperability evaluation consists of discovering the semantic losses when interoperation occurs and then qualifying their effects on the interoperation. Based on the mathematical formalization of the semantic relationship, we proposed two measures, the potential $(v)$ and the effective $(\varepsilon)$ interoperability, for assessing the interoperability between two Information Systems (ISs). A map of interoperability measures (figure 1) makes it easier not only to identify the semantic gap (the missing part of semantics that causes a problem of understanding by the receiving system), but also to evaluate what must be done to improve the interoperation. 


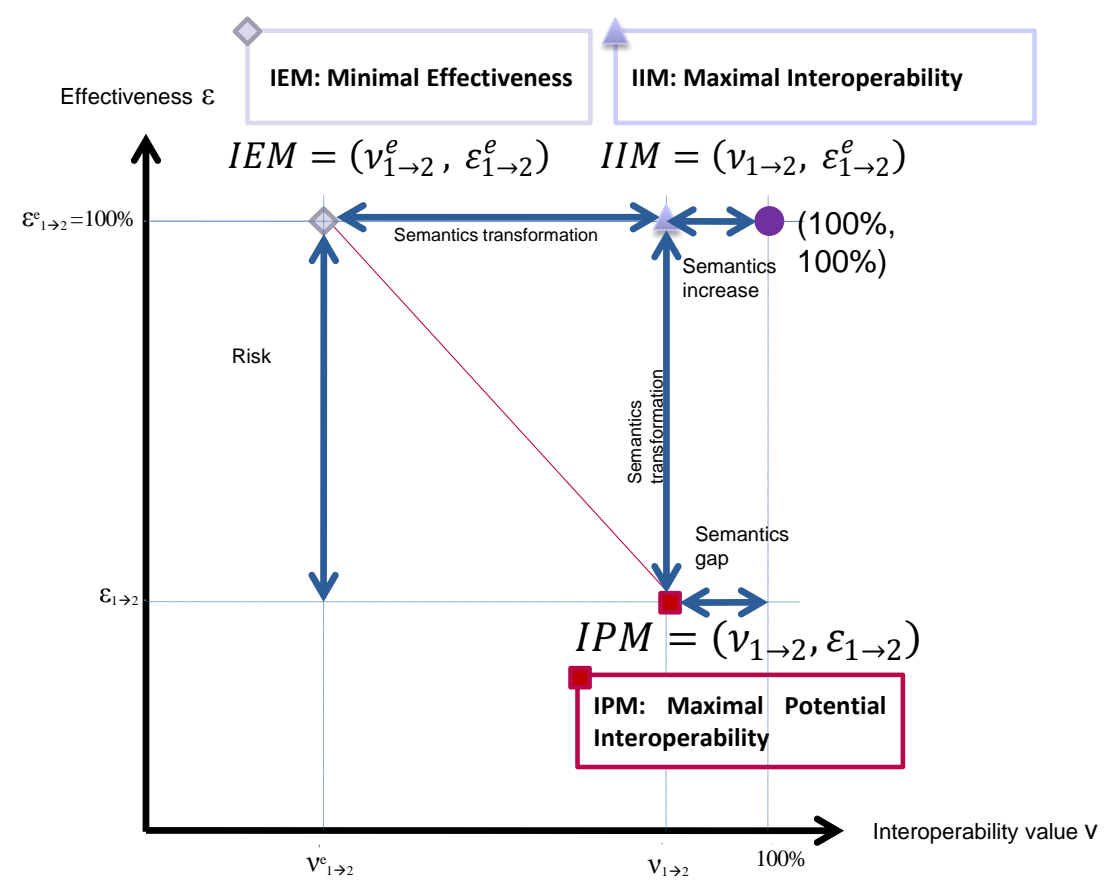

Figure 1. Map of Interoperability Measures

\section{Perspectives}

We proposed a formal approach to interoperability assessment that provides measures in order to assess quantitatively and qualitatively the interoperation between collaborative information systems. One of our perspectives is to apply our formal approach with different maturity models that are mainly based on semiformal evaluation (Panetto 2007, Ford et al. 2007). In addition, we have defined the various actions that the collaborative enterprises could take to improve their potential and effective interoperability. Future research should detail how this action could be conducted: that is, how to add semantics when studying a the interoperation from one way of exchange (of information) and what the effect of that transformation could be on the interoperation in the other way? We are studying the possible correlation between both interoperation directions.

\section{References}

Ford, T., J. Colombi, S. Graham, and D. Jacques. 2007. "The Interoperability Score.” Paper presented at the Fifth Conference on Systems Engineering Research, Hoboken, NJ (US), 14-16 March.

IEEE (International of Electrical and Electronics Engineers). 1990. Standard Computer Dictionary: A Compilation of IEEE Standard Computer Glossaries. New York: IEEE.

Panetto, H. "Towards a Classification Framework for Interoperability of Enterprise Applications." International Journal of Computer Integrated Manufacturing 20 (8): 727-740.

Tassey, G., S. B. Brunnermeier, and S. A. Martin. 1999. "Interoperability Cost Analysis of the US Automotive Supply Chain.” Research Triangle Institute Final Report. RTI Project 7007-03. NIST report, Gaithersburg, MD, USA

Yahia, E., M. Lezoche, A. Aubry, and H. Panetto. 2011. "Semantics Enactment in Enterprise Information Systems." Proceedings of the 18th IFAC World Congress 18 (1): 1306413073. Milan, Italy: IFAC (International Federation of Automatic Control). Available through IFAC-Papers Online, doi:10.3182/20110828-6-IT-1002.03597. 